УдК 636.933.085

https://doi.org/10.32634/0869-8155-2021-354-11-12-76-80

Краткий обзор/Brief review

Карынбаев А.К. 1 ,

Юлдашбаев Ю.А. ${ }^{2}$,

Кузембайулы Ж. ${ }^{3}$

${ }^{1}$ Международный Таразский Инновационный институт, Тараз, Республика Казахстан

E-mail: uzniijr.taraz@mail.ru

2 РГАУ - МСХА имени К.А. Тимирязева, Россия, г. Москва, ул. Тимирязевская, д. 49

3 Шымкентский Университет, г. Шымкент, Республика Казахстан

E-mail: kuzembayuly45@mail.ru.

Ключевые слова: пустынные пастбища, система использования, поедаемый кормовой запас, проективное покрытие, кормовая ценность травостоя, пастбищный период, сезонное использование

Для цитирования: Карынбаев А.К., Юлдашбаев Ю.А., Кузембайулы Ж. Влияние систем использования на продуктивность кустарниково-эфемеровых пустынных пастбищ и сохранность травостоя. Аграрная наука. 2021; 354 (11-12): 76-80.

https://doi.org/10.32634/0869-8155-2021-354-11-12-76-80

Конфликт интересов отсутствует

Amanbai K. Karynbaev',

Yusupzhan A. Yuldashbaev²,

Zharylkasyn Kuzembayuly ${ }^{3}$

${ }^{1}$ The International Taraz Innovation Institute, Taraz,

Republic of Kazakhstan

E-mail: uzniijr.taraz@mail.ru

${ }^{2}$ RGAU - Moscow Agricultural Academy named after K.A. Timiryazev, Russia, Moscow, Timiryazevskay st., 49

${ }^{3}$ Shymkent University, Shymkent, Republic of Kazakhstan

E-mail: kuzembayuly45@mail.ru.

Key words: desert pastures, the system of use, the feed stock being eaten, the projective cover the fodder value of the herbage, the pasture period, seasonal use

For citation: Karynbayev A.K.,

Yuldashbayev Y.A., Kuzembayuly Zh. The influence of use systems on the productivity of shrub-ephemeral desert pastures and the preservation of herbage. Agrarian Science. 2021; 354 (11-12): 76-80. (In Russ.)

https://doi.org/10.32634/0869-8155-2021-354-11-12-76-80

There is no conflict of interests
Влияние систем использования на продуктивность кустарниковоэфемеровых пустынных пастбищ и сохранность травостоя

\section{PEЗЮME}

Статья посвящена актуальной проблеме разработки научно обоснованной организации использования отгонных пастбищ на юге Казахстана. Установлено, что состав и разнообразие пастбищных трав оказывают заметное влияние на кормовую ценность травостоя и в конечном счете отражаются на кормоемкости пустынных пастбищ. Выпас сельскохозяйственных животных необходимо проводить с оптимальной нагрузкой на пастбища, то есть стравливать травостой на пастбище не более $70 \%$ от продуктивности пастбищного травостоя. В результате лучшей сохранности различных видов кормовых растений и в целом пастбищного травостоя при системном использовании урожайность пастбищ в летний сезон составила 6,15 ц/га, что выше по сравнению с бессистемным выпасом (5,20 ц/га) почти на 1,0 ц/га сухой кормовой массы. Все стравленные ранней весной пастбищные растения через 10-15 дней дали отаву и хорошо сохранились от перетравливания и вытаптывания.

\title{
The influence of use systems on the productivity of shrub- ephemeral desert pastures and the preservation of herbage
}

\section{ABSTRACT}

The article is devoted to the urgent problem of developing a scientifically based organization and use of distant pastures in the south of Kazakhstan. It has been found that the composition and diversity of pasture grasses have significant effect on the forage value of the grass stand and ultimately affect the forage capacity of desert pastures. Grazing of farm animals should be carried out with an optimal load on pastures, that is, no more than $70 \%$ of the productivity of the pasture mass should be exploited. Due to the better preservation of various types of forage plants and pasture herbage in general with systematic use, the yield of pastures in the summer season was $6.15 \mathrm{c} / \mathrm{ha}$, in other words it was higher by almost $1.0 \mathrm{c} /$ ha of dry forage mass compared to unsystematic grazing $(5.20 \mathrm{c} / \mathrm{ha})$. All pasture plants exploited in early spring produced aftermath in $10-15$ days and were well preserved from overexploitation and trampling.

Поступила: 10 июня

После доработки: 15 июня

Принята к публикации: 10 сентября 


\section{Введение}

Пустынные пастбища Казахстана таят в себе огромные резервы развития пустынного животноводства и в первую очередь овцеводства и верблюдоводства. Поэтому перспективы их развития рассматриваются в тесной связи с рациональным использованием естественных пастбищ.

Естественные кормовые угодия, составляющие основу кормовой базы животноводства Республики Казахстан, характеризуются значительным разнобразием по ботаническому составу травостоя, кормовой ценности и продуктивности не только в целом по пустынной зоне республики, но и в каждой области, районе и хозяйстве.

В последние десятилетия природные кормовые ресурсы здесь используются неравномерно, без определенной системы, что вызывает снижение кормовой продуктивности, выхода продукции животноводства, а затем и деградацию пастбищ.

В настоящее время в результате длительного бессистемного выпаса пастбищ 25 млн га сбиты и 30 млн га подвержены различным видам эрозии почв и изменениям растительности. Поэтому использование пастбищ и поддержание их продуктивности на достаточно высоком уровне должны включать систему охраны целостности важнейших зональных типов биогеоценозов, их структуры, а также сохранение естественных сил самовосстановления популяций и комплекса в целом.

Одна из форм охраны растительности - ее рациональное использование. Системная эксплуатация пустынных пастбищ с соблюдением оптимальных нагрузок в значительной степени гарантирует сохранение их состава и продуктивности. При такой эксплуатации пастбищ возможно применение комплекса многих мероприятий: сезонное чередование пастбищ в зонах, определенная нагрузка на пастбище, мероприятия по уходу, улучшению, обводнению и т.д. Только таким путем можно остановить антропогенное воздействие на процессы опустынивания природных экосистем.

Для правильного использования пастбищ необходимы прежде всего данные о влиянии выпаса на развитие растительности. Изучение влияния отчуждения на урожай и ботанический состав пастбищ в последующие годы дает возможность наметить, сколько лет и в какой сезон можно использовать их, не снижая количества и качества травостоя. При этом выпас оказывает различное влияние на изменение растительного покрова и накопление кормовой массы.

Анализируя современное состояние пустынных пастбищ республики, И.И. Алимаев утверждает, что в результате бессистемного использования естественных пастбищных угодий сбито около 10\% пастбищ, а на 50\% пастбищной территории кормовая растительность деградирована, засорена непоедаемыми и ядовитыми растениями [1]

В целом сохранение, восстановление и повышение продуктивности природных кормовых угодий Казахстана являются важнейшими проблемами огромной пустынной зоны республики и приоритетом при проведении комплексных исследований по их рациональному использованию.

Актуальность разработки системы рационального использования естественных кормовых угодий,

особенно в аридной зоне республики, указана в работах ряда ученых нашей республики [2, 3, 4, 5].

Имеются многочисленные исследования, направленные на изучение влияния рационального использования пастбищ на их состояние и продуктивность животных [6, $7,8]$. Все они отмечают, что правильное использование пастбищ увеличивает их продуктивность на 20-30\%. Указывается также, что при рациональном использовании пастбищные травы стравливаются за 5-6 дней, а умеренное стравливание в любой сезон не вредит пастбищным растениям. Предоставление отдыха дает прибавку урожая на 25-40\%, при этом коэффициент использования травостоя повышается в 1,5-2 раза.

Анализ имеющейся литературы показывает, что работы, посвященные проблемам рационального использования песчаной пустыни Кызылкум, традиционной для пустынных отраслей животноводства, отсутствуют, в настоящее время никто этим не занимается.

\section{Методика исследований}

В соответствии с методикой исследований и программой проведения НИР изучение динамики развития и сохранности кормовых растений кустарниково-эфемерового типа пастбищ песчаной пустыни Кызылкум на юге Казахстана при различной системе их использования были проведены по указанной схеме полевого опыта (табл. 1).

Как известно, при бессистемном (вольном) выпасе отсутствует регулирование порядка использования пастбищ, и животные используют их в течение года без учета их состояния и кормовой продуктивности.

При системном (загонно-участковом) выпасе опытные пастбища использовались первый раз ранней весной, когда в основном стравливаются ранневесенние эфемеры, эфемероиды и пастбищное разнотравье с соблюдением оптимальной нагрузки в течение 7-10 дней. При этом было стравлено до 60-70\% от их кормовой массы. Все стравленные ранней весной пастбищные растения через 10-15 дней дали отаву и хорошо сохранились от перетравливания и вытаптывания.

Большинство кустарниково-эфемеровых пастбищ песчаной пустыни при указанной загонно-участковой системе выпаса вторично используются в осенне-зимний сезоны.

Методической основой изучения организации и использования пустынных пастбищ различных природных зон служили «Инструкция к методике ботанико-кормового обследования сенокосных и пастбищных угодий на территории Казахстана» [9], методика опытов на сенокосах и пастбищах [10] и методика расчета обменной энергии в кормах на основе содержания сырых питательных веществ [11].

Химический анализ растительной массы с различных сезонных пастбищ проводился в лаборатории анализа

Таблица 1. Схема полевых опытов по изучению организации и использования пастбищ кустарниково-эфемерового типа песчаной пустыни Кызылкум при различных системах их использования

Table 1. Scheme of field experiments to study the organization and use of pastures of the shrubephemeral type of the sandy Kyzyl Kum desert with a different systems of their use

Варианты природных зон

Пастбища песчаной пустыни Кызылкум

\section{Варианты использования пастбищ}

Пастбища бессистемного выпаса (контроль)

Пастбища системного (загонно-участкового) использования (опыт) 
кормов ТОО «КазНИИЖиК» анализатором FOSS NIRS DS 2500 (Швеция) № серии 91714226 (2011 г.в.).

\section{Результаты исследований}

В соответствии с планом работ по реализации проекта проведено геоботаническое обследование основных типов пастбищ песчаной пустыни Кызылкум.

Кустарниково-эфемеровые пастбища распространены в песчаной пустыне. В южном Казахстане они занимают большие площади (2 млн га), покрывая большую часть территории пустыни Кызылкумов.

Кустарниковые пастбища связаны в своем распространении с закрепленными песками, поверхность которых скреплена более или менее густым сплетением корней и корневищ.

Как правило, рельеф кустарниково-эфемеровых пастбищ сильно расчлененный и очень редко - равнинный.

Как показали проведенные исследования, растительность песчаных пустынь отличается богатством видов и разнообразием их биологических и хозяйственных свойств. В составе растительности имеются древовидные кустарники, кустарники, полукустарники, многолетники и травянистые однолетники. Но везде главными представителями растительного покрова являются саксаул белый (Haloxylon persicum) и осока вздутая (Carex physodes M. Bieb).

Растительность кустарниково-эфемеровых пастбищ в основном представлена характерными видами песчаных пустынь: саксаул белый (Haloxylon persicum), черный (Haloxylon aphyllum Iljin), кустарники - жузгун (Calligonum aphyllum, C. platyacanthum), песчаная акация (Ammodendron argenteum, A. conollyi), астрагалы (Astragalus turczaninowii Kar. et Kir.), эфедра (Ephedra), полукустарники - полынь белоземельная (Artemisia terrae albae) и песчаная (Artemisia arenaria DS), терескен (Krascheninnikovia ceratoides (L.) Gueldenst.), изень (Kochia arenaria Roth), кейреук (Salsola rigida, S. laricina), из травянистых - селин (Aristida L.), пырей пустынный (Agropyron desertorum (Fisch.) Schult. et. Schult. f.), мятлик луковичный (Poa alpina, P. bulbosa), мортук Бонопарта (Eremopyrum bonaepartis), гусиный лук (Allium monadelphum, A. polyphylum).

В грядовых песках Кызылкумов часто встречаются комплексные пастбища, состоящие из пастбищ кустарниково-эфемерового типа, располагающихся по верхним частям склонов, и пастбищ полынно-эфемерового типа, закустаренных в основном черным саксаулом, находящихся на нижних частях склонов, часто в долинах.

Характерной особенностью пастбищ бугристо-грядовых песчаных пустынь северной зоны Кызылкумов является то, что по мере углубления в пески серополынники постепенно уступают место крупнокустарникам.

Весной, в период массовой вегетации эфемеров, овцы питаются исключительно зеленым кормом, в основном поедая осоку (Carex physodes M. Bieb), мятлик луковичный (Poa alpine, $P$. bulbosa), костер кровельный (Bromus tectorum L.), мортук Бонопарта (Eremopyrum bonaepartis), ковыль волосатик, (Stipa capillata L.), рогач песчаный (Ceratocarpus arearius L.) и другие пастбищные разнотравья. Валовая урожайность весенних пастбищ в среднем составляет 4,15 ц/га, из них поедае- мый овцами кормовой запас $-1,63$ ц/га сухой кормовой массы (табл. 2).

Результаты исследований показали, что кустарниково-эфемеровые пастбища дают наивысшее общее (валовое) количество зеленой массы среди остальных кормовых угодий пустыни. Например, летом такая масса достигает 5,20 ц с 1 га в результате обильного развития зеленых ассимиляционных веточек саксаула.

Однако из такого большого для пустыни количества растительной массы овцами может быть использована лишь сравнительно небольшая часть: 2,10 ц с 1 га сухой кормовой массы.

Летом основу питания овец составляет сухой хас и частично сохраняющиеся на корню высохшие и выцветшие стебли осок и разнотравье. К ним присоединяется некоторое количество вегетирующих летом растений, таких как жузгун кызылкумский (Calligonum kzylkumi Pavl.), молочаи (Euphorbia turczaninowii Kar. et Kir.), дающих зеленый корм. Составляющий основу валовой урожайности саксаул белый (Haloxylon persicum) в указанный период кормом для овец не служит, поэтому поедаемый запас летних пастбищ песчаной пустыни сравнительно небольшой и составляет в среднем 2,10 ц/га сухой массы.

Проведенные наблюдения показали, что на основных типах песчаных пустынь травостой начинает развиваться постепенно, с появлением первых теплых весенних дней, что обычно начинается с первой декады марта. Одни из растений, например многолетние эфемероиды - рогач песчаный (Ceratocarpus arenarius L.), осока вздутая, песчаная (Cárex rostráta), осока толстостолбиковая, пустынная (Carex pachystylis), появляются сразу же после отхода снега, затем последовательно появляются мятлик луковичный (Poa bulbosa L.), эфемеры мортуки (Eremopyrum bonaepartis), костры (Anisantha), начинают вегетировать кустарники. Все эти растения весь цикл своего развития, вплоть до плодоношения, завершают в течение весеннего периода.

Динамика развития основных групп отдельных кормовых растений песчаной пустыни в весенний период составляет (в \%):

- эфемеры: костры, мортуки и др. 100

- эфемероиды 100

- злаки: ковыли, аристида и др.

- бобовые: астрагалы, жантак и др.

- разнотравье: гелиетропы,к ермек,

псаролеи, васильки, горчаки и др. $30-60$

- полыни разные

- солянки: кейреук, ебелек и др.

- кустарники: джузгуны,

акация песчаная и др. ний период оказывает значительное влияние на коли-

Таблица 2. Валовая урожайность и поедаемый овцами кормовой запас пастбищ песчаной пустыни Кызылкум в весенне-летний сезоны их использования (ц/га сухой кормовой массы)

Table 2. Gross yield and feed stock of pastures in the Kyzyl Kum sandy desert consumed by sheep in the spring-summer seasons of their use (centner / ha of dry feed mass)

\begin{tabular}{|l|c|c|c|}
\hline \multicolumn{1}{|l|}{ Группы типов пустынных пастбищ } & Урожайность, ц/га & \multicolumn{2}{|c|}{ Сезоны использования } \\
\hline $\begin{array}{l}\text { Кустарниково-эфемеровые песчаной } \\
\text { пустыни Кзылкум }\end{array}$ & весна & лето \\
\hline
\end{tabular}


чественно-качественные показатели состояния растительного покрова.

При бессистемном (вольном) выпасе проективное покрытие пастбищ в среднем составляет 40\%, количество видов основных кормовых растений -30 , средняя высота пастбищного травостоя - 10-15 см, урожайность - 4,15 ц/га сухого корма.

Аналогичные показатели кустарниково-эфемеровых пастбищ песчаной пустыни Кызылкум при системном использовании с введением условно загонно-участкового выпаса в весенний период использования составляют соответственно 60\%, 50 видов, 20-35 см, 5,75 ц/ га, что по всем показателям значительно выше, чем у аналогичных пастбищ бессистемного выпаса (табл. 3).

Качество травостоя указанных пастбищ от весны к летнему периоду сильно изменяется. Многие эфемеры, представляющие ценную часть весеннего травостоя, засыхают, обламываются и исчезают, вследствие чего питательность травостоя пастбищ резко снижается. Полынь обычно в летнюю пору впадает в состояние анабиоза, у нее желтеют листочки и подсыхают кончики веточек.

На песчаных пастбищах в период летнего сухостояния большую роль как витаминные корма играют редкие вегетирующие летом растения - кандымы (Calligonum), астрагалы (Astragalus), молочай (Euphorbia), солянка хрящеватая (S. sclerantha C. A. Мey), солянка малолистная, чогон (Aellenia subaphylla), прибрежница, ажырық (Aeluropus littoralis).

На песчаных пастбищах очень важно соблюдать умеренный выпас, поскольку рыхлость субстрата создает опасность обарханивания и ухудшения пастбищ. Поэтому такие пастбища целесообразно использовать однократно, в одном сезоне и не более 2-3 лет подряд, после чего необходимо менять сезон использования.

Динамика развития и сохранность основных групп и отдельных кормовых растений основных типов пастбищ песчаной пустыни Кызылкум в летний период составляет (в \%):
- эфемеры: костры, мортуки и др.

- эфемероиды

- злаки: ковыли, аристида и др.

- бобовые: астрагалы, жантак и др.

- разнотравье

- полыни разные

- солянки: кейреук, ебелек и др.

- кустарники: джузгуны, акация песчаная

и др

Из приведенного перечня видно, что в летний сезон эфемеры (однолетники) и эфемероиды (многолетники) заканчивают свое развитие и большинство из них выгорают и сохраняют на корню 55-65\% их кормовой массы, тогда как остальные группы и виды кормовых растений вегетируют и сохраняются почти полностью.

При определении проективного покрытия поверхности почвы пастбищной растительностью установлено значительное снижение указанного показателя при бессистемном выпасе (35\%) по сравнению с системным (условно загонно-участковым) использованием (52\%).

В летний период из-за исчезновения из травостоя мелкого разнотравья и эфемеров вследствие их чрезмерного перетравливания и вытаптывания при бессистемном использовании сократилось количество видов кормовых растений с 41 до 23. При системном использовании средняя высота пастбищного травостоя была выше (25-40 см) по сравнению с бессистемным выпасом (15-20 cM).

В основном из-за лучшей сохранности различных видов кормовых растений и в целом пастбищного травостоя при системном использовании урожайность пастбищ в летний сезон составила 6,15 ц/га, что выше по сравнению с бессистемным выпасом (5,20 ц/га) почти на 1,0 ц/га сухой кормовой массы.

Предусмотренные в плане реализации пректа исследования по изучению влияния различных систем использования природных пастбищ песчаной пустыни Кызылкум продолжаются согласно календарному плану работы.
Таблица 3. Количественно-качественные показатели состояний растительного покрова пастбищ Кызылкумских песков в весенний период, 2021 г.

Table 3. Quantitative and qualitative indicators of the state of the vegetation cover of the Kyzyl Kum sands pastures in the spring, 2021

\section{Варианты способа использования пастбищ}

Проективное
покрытие, \%
выпаса (контроль)

Пастбища системного

(условно-загонно-участкового) использования (опыт)

60

\begin{tabular}{|l|l|l|}
\hline$\%$ & Ко \\
\hline
\end{tabular}
УрожайCM ность, ц/га
4,15

50

20-35

5,75

Таблица 4. Количественно-качественные показатели состояний растительного покрова пастбищ Кзылкумских песков в летний период использования, 2021 г.

Table 4. Quantitative and qualitative indicators of the state of the vegetation cover of the Kyzyl Kum sands pastures during the summer period of use, 2021

\begin{tabular}{|l|c|c|c|c|}
\hline $\begin{array}{l}\text { Варианты способа использования } \\
\text { пастбищ }\end{array}$ & $\begin{array}{c}\text { Проективное } \\
\text { покрытие, \% }\end{array}$ & $\begin{array}{c}\text { Количество } \\
\text { видов }\end{array}$ & $\begin{array}{c}\text { Высота тра- } \\
\text { востоя, см }\end{array}$ & $\begin{array}{c}\text { Урожай- } \\
\text { ность, ц/га }\end{array}$ \\
\hline $\begin{array}{l}\text { Пастбища бессистемного } \\
\text { Выпаса (контроль) }\end{array}$ & 35 & 23 & $15-20$ & 5,20 \\
\hline $\begin{array}{l}\text { Пастбища системного } \\
\text { (загонно-участкового) } \\
\text { использования (опыт) }\end{array}$ & 52 & 41 & $25-40$ & 6,15 \\
\hline
\end{tabular}

\section{Выводы}

Способ использования песчаных пастбищ в весенний период оказывает значительное влияние на количественно - качественные показатели состояния растительного покрова.

При бессистемном (вольном) выпасе проективное покрытие пастбищ в среднем составило 40\%, количество видов основных кормовых растений - 30, средняя высота пастбищного травостоя - 10-15 см, урожайность - 4,15 ц/га сухого корма. Аналогичные показатели кустарниково-эфемеровых пастбищ песчаной пустыни Кызылкум при системном использовании с введением условно загонно-участкового выпаса в весенний период использования составили соответственно 60\%, 50 видов, 20-35 см, 5,75 ц/га, что по всем показателям значительно выше, чем у аналогичных пастбищ бессистемного выпаса.

Выпас сельскохозяйственных животных необходимо проводить с оп- 
тимальной нагрузкой на пастбища, то есть стравливать травостой на пастбище не более $70 \%$ от продуктивности пастбищного травостоя.

Непременным условием рационального использования пастбищ является ежегодное изменение сроков начала выпаса.

\section{ЛИТЕРАTYPA/REFERENCES}

1. Алимаев И.И. Восстановление деградированных пастбищных земель в аридных регионах Казахстана. // Сб. : научных трудов КазНИИК и П. - Алматы, 1977.-28 с. [Alimaev I.I. Restoration of degraded pasture lands in arid regions of Kazakhstan. // Collection : scientific works of kazNIIK and P. Almaty, 1977.-28 p.]

2. Жамбакин Ж.А., Молдабекова К.М. Влияние выпаса на структуру и продуктивность серополынников Южного Прибалхашья. -Вестник сельскохояйственной науки.Алма-Ата, 1975 - №8,- c. 60-63. [Zhambakin Zh.A., Moldabekova K.M. Influence of grazing on the structure and productivity of seropolynnik of the Southern Balkhash region. -Bulletin of Agricultural Science.AlmaAta, 1975. - No. 8,- pp. 60-63.]

3. Тореханов А.А. Проблемы кормопроизводства в Казахстане. Вестник с. -х. Науки Казахстана. 2004.- №10.- с. 11-13. [Torekhanov A.A. Problems of feed production in Kazakhstan. Bulletin of Agricultural Science of Kazakhstan. 2004.- No. 10.- pp. 11-13]

4. Тореханов А.А. Проблемы кормопроизводства в Казахстане. Вестник с.-х. Науки Казахстана. 2004.-№2. - с.16-17. [Torekhanov A.A. Problems of feed production in Kazakhstan. Bulletin of Agricultural Science of Kazakhstan. 2004.-No. 2. pp. 16-17.]

5. Тореханов А.А. Экологичские основы сохранения пастбищ аридной зоны. Вестник с.-х. науки Казахстана. 2007.№2. - c.14-16. [Torekhanov A.A. Ecological foundations of conservation of pastures of the arid zone. Bulletin of Agricultural Science of Kazakhstan. 2007.-No. 2. - pp.14-16.]

6. Насиев Б.Н., Маканова Г.Н., Рзаев Н. Факторы деградации кормовых угодий полупустынной зоны. //Известия Национальной Академии наук Республики Казахстан. - 2014. - №4 (22). - C. 34-36. [Nasiev B.N., Makanova G.N., Rzaev N.

\section{ОБ АВТОРАX:}

Карынбаев Аманбай Камбарбекович, доктор сельскохозяйственных наук, академик Российской академии естественных наук

Юсупжан Артыкович Юлдашбаев, академик Российской академии наук, доктор сельскохозяйственных наук, професcop

Кузембайулы Жарылкасын, доктор сельскохозяйственных наук, профессор
Работа выполнена в рамках научно-технической программы ПЦФ МСX РК на 2021-2023 годы на НТП BR10764915 «Разработка новых технологий восстановления и рационального использования пастбищ (использование пастбищных ресурсов)».

Factors of degradation of forage lands of the semi-desert zone. // Proceedings of the National Academy of Sciences of the Republic of Kazakhstan. - 2014. - №4 (22). - Pp. 34-36.]

7. Мешетич В.Н., Аяганов А.Б. Сенокосы и пастбища - пришло время восстановления //Агро Информ. - 2013. -№4. - с. 2. [Meshetich V.N., Ayaganov A.B. Hayfields and pastures - it's time to restore //Agro Inform. - 2013. - No. 4. - p. 2.]

8. Күзембайұлы ж.,Карынбаев А.К. Состав и питательность кормов юго-западного региона Казахстана (справочное пособие) Издатель: Heinrich-Bocking-str.6-8.66121 Saarbrucken. Deutschland/Германия [Kuzembayuly Zh., Karynbayev A.K. Composition and nutritional value of feed in the south-western region of Kazakhstan (reference manual) Publisher: HeinrichBocking-str.6-8.66121 Saarbrucken.Deutschland/Germany]

9. Р КАЗАХСТАН - Инструкция и методика проведения ботанико-кормового обследования сенокосных и пастбищных угодий территории Казахстана. - Алма -Ата, 1969. 30 страниц [Republic OF KAZAKHSTAN - Instructions and methods for conducting a botanical and forage survey of hay and pasture lands in Kazakhstan. - Alma-Ata, 1969. 30 pages]

10. Методика опытов на сенокосах и пастбищах. ВНИИк, Москва, 1971.- 132 с. [Methods of experiments on hayfields and pastures. VNIIK, Moscow, 1971.- 132 p.]

11. М.П. Кирилов, Е.А.Махаев, Н.Г. Первов, В.В, Пузанова, А.С. Аникин

Методика расчета обменной энергии в кормах на основе содержания сырых питательных веществ (для крупного рогатого скота, овец и свиней) ГНУ «ВНИИЖ Россельхозакадемии» Дубровицы 2008. 24 стр. [M.P. Kirilov, E.A.Makhaev, N.G. Pervov, V.V., Puzanova, A.S. Anikin [Methodology for calculating the exchange energy in feed based on the content of raw nutrients (for cattle, sheep and pigs) GNU «VNIIZH of the Russian Agricultural Academy» Dubrovitsy 2008. 24 p.]

\section{ABOUT THE AUTHORS:}

Karynbaev Amanbai Kambarbekovich, Doctor of Agricultural Sciences, Academician of the Russian Academy of Natural Sciences

Yusupzhan Artykovich Yuldashbaev, Academician of the Russian Academy of Sciences, Doctor of Agricultural Sciences, Professor Kuzembayuly Zharylkasyn, Doctor of Agricultural Sciences, Professor

\section{НОВОСТИ•НОВОСТИ•НОВОСТИ•НОВОСТИ॰}

\section{На Алтае разработана технология ресурсосбережения для обработки засушливых земель}

Учеными НОЦ алтаистики и тюркологии «Большой Алтай» Алтайского государственного университета совместно с коллегами из Германии и Казахстана разработана технология ресурсосбережения для обработки засушливых земель, сообщила пресс-служба АлтГУ. Ресурсосбережение - важный тренд для современного общества, отметил доцент кафедры экономической географии и картографии АлтГУ Андрей Бондарович. Инновационные технологии рассчитаны на то, чтобы без полива сохранить влагу, используя внутренний потенциал водного режима.
На территории Казахстана и Алтайского края были развернуты агрометеорологические стационары - автоматические метеорологические станции с датчиками, установленными на трех разных глубинах, которые измеряли такие параметры как температуру, влажность и доступность почвенной влаги для растений.

Станции сохраняют полученные данные в системе и могут транслировать их онлайн. Это позволяет исследователям проводить интерактивный анализ и определять, достаточно ли внутренних водных ресурсов для растений, пояснил Бондарович. Результаты анализа дают возможность экономить воду или, в некоторых случаях, минимально обрабатывать почву, чтобы влага проникала на глубину и в течение сезона более равномерно расходовалась растениями, уточнил доцент кафедры экономической географии и картографии АлтГУ. 


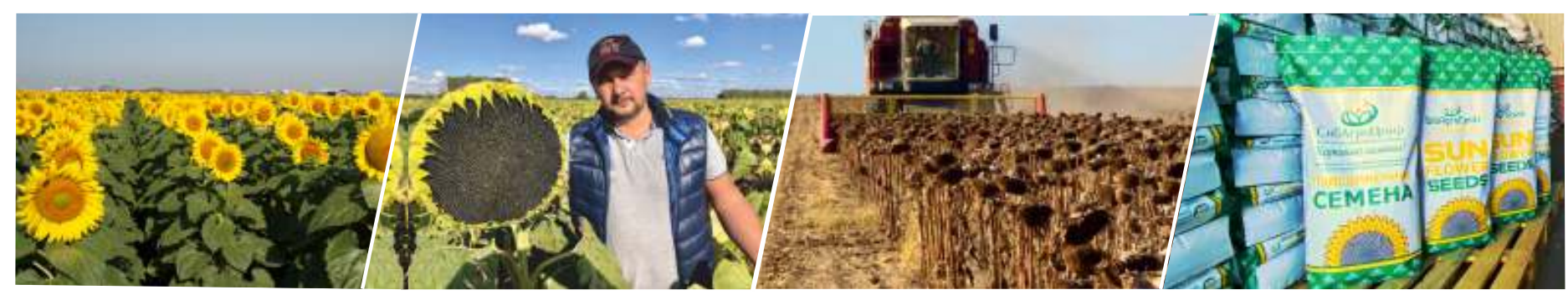

\section{НОВЫЕ ГИБРИДЫ ЛИДЕРЫ В СВОЕЙ \\ ГРУППЕ СПЕЛОСТИ}

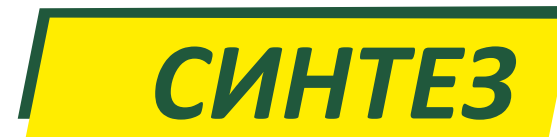

СКОРОСПЕЛЫЙ МАСЛИЧНЫЙ

Потенциальная урожайность 40-42 ц/га Масличность 50-52\%

8000 руб/П.е. (150 тыс.шт., Максим XL+биостимулятор)

500 руб/кг (без обработки)

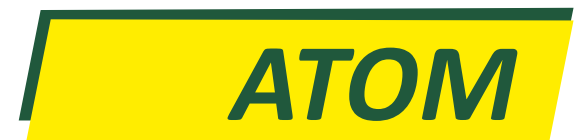

РАННЕСПЕЛЫЙ МАСЛИЧНЫЙ

Потенциальная урожайность 45-48 ц/га Масличность 49-52\%

7500 руб/п.е. (150 тыс.шт., Максим XL+биостимулятор) 450 руб/кг (без обработки)

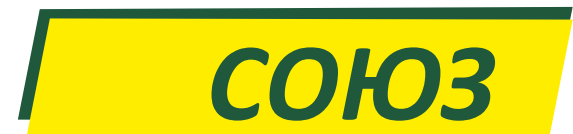

СКОРОСПЕЛЫЙ МАСЛИЧНЫЙ

Потенциальная урожайность 42-45 ц/га Масличность 48-50 \%

8000 руб/п.е. (150 тыс.шт., Максим XL+биостимулятор) 500 руб/кг (без обработки)

\section{ЮНИОН}

РАННЕСПЕЛЫЙ МАСЛИЧНЫЙ

Потенциальная урожайность 47-49 ц/га Масличность 50-53\%

7500 руб/п.е. (150 тыс.шт., Максим XL+биостимулятор) 450 руб/кг (без обработки)

В рамках государственной программы импортозамещения в научнопроизводственном объединении «Алтай» созданы новые высокопродуктивные скороспелые гибриды и сорта подсолнечника, ПРЕДНАЗНАЧЕННЫЕ ДЛЯ ВСЕХ ЗОН ВОЗДЕЛЫВАНИЯ.

\section{HOBbIE COPTA ПРЕДНАЗНАЧЕНЫ ДЛЯ}

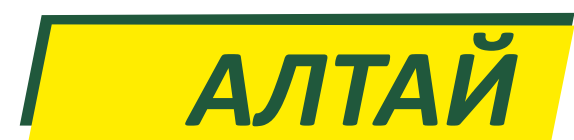

КРУПНОПЛОДНЫЙ КОНДИТЕРСКИЙ

Высокая рентабельность.

Масса 1000 семянок - 155 г.

Потенциальная урожайность 40-42 ц/га

ЭС: 350 руб/кг, 3900 руб/п.е.

РC 1: 250 руб/кг, 3000 руб/п.е.

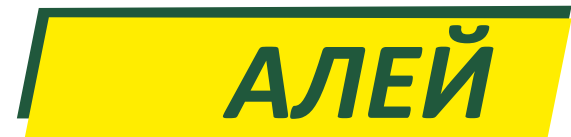

СКОРОСПЕЛЫЙ МАСЛИЧНЫЙ

Засухоустойчивый,

масличность 52-56 \%

Потенциальная урожайность 38-40 ц/га

ЭС: 230 руб/кг, 3500 руб/п.е.

PC 1: 137 руб/кг, 2500 руб/п.е.

НАШИ ПАРТНЕРЫ - БОЛЕЕ 500 СЕЛЬХОЗПРЕДПРИЯТИЙ И АГРОХОЛДИНГОВ РОССИИ И КАЗАХСТАНАІ

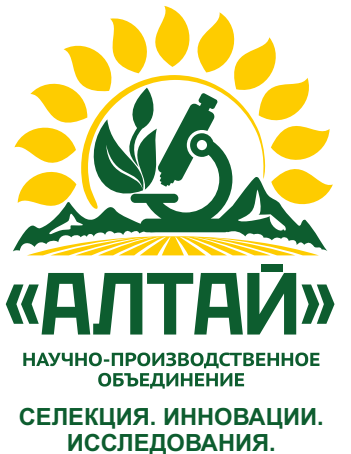

ИССЛЕДОВАНИЯ.
Алтайский край, г. Рубцовск, Угловский тракт, 67Д 8 (385-57) 4-07-17, 8-906-965-93-26, 8-960-964-89-86 8-800-707-71-88 звонок по России бесплатный www.sibagrocentr.ru; e-mail: sibagrocentr@mail.ru

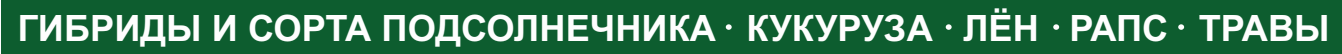
НАШИ СЕМЕНА ВЫРАЩЕНЫ НА БЛАГОДАТНЫХ ЗЕМЛЯХ АЛТАЯ ОРГАНИЗУЕМ БЕСПЛАТНУЮ ДОСТАВКУ В ВАШ РЕГИОН! 